\title{
KECERNAAN KULIT DAGING BUAH KOPI DENGAN FERMENTASI MOL (MIKROORGANISME LOKAL) DALAM RANSUM PELET PAKAN KELINCI PERANAKAN REX
}

\author{
Digestibility of Pod Coffee Fermented with Local Microorganism (LMO) in Pellet Diet \\ Rex Rabbit
}

\author{
Fathi Akbar Nasution ${ }^{1}$, Iskandar Sembiring ${ }^{2}$ dan Hamdan ${ }^{2}$ \\ 1. Mahasiswa Program Studi Peternakan Fakultas Pertanian Universitas SumateraUtara \\ 2. Staf Pengajar Program Studi Peternakan Fakultas Pertanian Universitas Sumatera Utara
}

\begin{abstract}
This research was conducted at the Laboratory of Biologi Ternak, University of Sumatra Utara on June 2014 until August 2014. This study aims to determine the effect of utilization fermented coffee pulp to dry matter and organic matter. This study used 20 male rex rabbits with average weight $913.05 \mathrm{~g} \pm 60.49 \mathrm{~g}$. The design used a completely randomized design (CRD) with 4 treatments and 5 replications. The treatments were diet containing fermented: non-fermented coffee pulp with ratio on treatment P0 (0\%: 30\%); P1 (10\%: 20\%); P2 (20\%: 10\%); and P3 (30\%: 0\%). The variable were observed that Dry Matter Digestibility (DMD) and Organic Matter Digestibility (OMD). The results showed that the average dry matter digestibility (\%) on treatment $P 0, P 1, P 2$, and $P 3$ were $59.70 ; 59.75 ; 59.74$; and 59.89, repectively, while the average organic matter digestibility (\%) 61.28; 61.40; 61.31; and 61.50, respectively. The result statistical analysis indicated that treatment were not significant affect $(P>0.05)$ on Dry Matter Digestibility $(D M D)$ and Organic Matter Digestibility (OMD). The conclusion of this study is fermented LMO (local micro organisme) has not significant effect on digestibility on rex rabbit.
\end{abstract}

Keywords : Digestibility, Coffee Pulp, Fermentation with LMO, Rex Rabbit.

\begin{abstract}
ABSTRAK
Penelitian ini dilakukan di Laboratorium Biologi Ternak, Universitas Sumatera Utara pada Juni 2014 sampai Agustus 2014. Penelitian ini bertujuan untuk mengetahui pengaruh pemanfaatan fermentasi kulit daging buah kopi untuk bahan kering dan bahan organik. Penelitian ini menggunakan 20 ekor kelinci rex jantan dengan berat rata-rata 913,05 g $\pm 60,49 \mathrm{~g}$. Rancangan yang digunakan adalah rancangan acak lengkap (RAL) dengan 4 perlakuan dan 5 ulangan. Pelet perlakuan yang mengandung fermentasi: non-fermentasi limbah kulit kopi dengan komposisi P0 (0\%: 30\%); P1 (10\%: 20\%); P2 (20\%: 10\%); dan P3 (30\%: 0\%). Variabel yang diamati bahwa Kecernaan Bahan Kering (KcBK), Kecernaan Bahan Organik (KcBO). Hasil penelitian menunjukkan bahwa rataan kecernaan bahan kering masing-masing (\%) pada P0, P1, P2, dan P3 adalah 59,70; 59,75; 59,74; dan 59,89, sedangkan kecernaan bahan organik rataan masing-masing (\%) 61,28; 61,40; 61,31; dan 61.50. Hasil analisis statistic menunjukkan bahwa perlakuan tidak signifikan (tidak mempengaruhi) $(\mathrm{P}>0,05)$ pada Kecernaan Bahan Kering (KcBK), Kecernaan Bahan Organik (KcBO). Kesimpulan dari penelitian ini adalah fermentasi MOL (micro organisme lokal) tidak signifikan (tidak mempengaruhi) terhadap daya cerna pada kelinci rex.
\end{abstract}

Kata kunci : Kecernaan, Kulit Daging Buah Kopi, Fermentasi dengan MOL, Kelinci Rex. 


\section{PENDAHULUAN}

Ketersediaan pakan merupakan salah satu faktor penting dalam usaha pemeliharaan ternak. Keberhasilan usaha pemeliharaan ternak banyak ditentukan oleh pakan yang diberikan disamping faktor pemilihan bibit dan tata laksana pemeliharaan yang baik. Agar kelinci dapat berproduksi tinggi, maka perlu dipelihara secara intensif dengan pemberian pakan yang memenuhi syarat, baik secara kualitas maupun kuantitas.

Pakan untuk kelinci pada dasarnya terdiri atas dua golongan, yaitu hijauan dan konsentrat. Hijauan adalah pakan yang mengandung serat kasar tinggi yang terdiri atas selulosa, hemiselulosa, pektin, dan memiliki kandungan energi yang tinggi dan protein yang rendah. Hijauan dapat diberikan sekitar $60-80 \%$ dan sisanya konsentrat. Menurut Sarwono (2002) bahan pakan kelinci dipilih yang disukai ternak. Bahan itu mudah didapat, dapat tersedia setiap saat dan nilai ekonomisnya relatif murah tidak bersaing dengan kepentingan manusia dan kandungan pakan cukup sesuai untuk kebutuhan hidup kelinci. Salah satu bahan pakan alternatif tersebut adalah kulit daging buah kopi.

Potensi pemanfaatan limbah sebagai bahan pakan ternak merupakan alternatif dalam meningkatkan ketersediaan bahan baku penyusun ransum. Limbah yang dimanfaatkan sebagai bahan baku pakan berasal dari bagian-bagian tanaman atau hewan yang dijadikan sebagai pakan kasar (roughage), sumber energi, sumber protein atau sumber mineral. Limbah kulit kopi dari sisa pengolahan biji kopi seharusnya bisa dimanfaatkan untuk alternatif komoditi lain, seperti pakan ternak, media tanam bagi jamur dan lain sebagainya.

Selain bermanfaat dalam mengurangi pencemaran lingkungan, juga dapat meningkatkan penghasilan petani kopi itu sendiri. Kulit daging buah kopi mengandung anti nutrisi berupa senyawa kafein 1,3\% dan tanin 8,5\%.Salah satu untuk menurunkan serat kasar kulit daging buah kopi serta menghilangkan kandungan tanin tersebut adalah dengan fermentasi. Fermentasi adalah proses penguraian unsur-unsur organik kelompok terutama karbohidrat untuk menghasilkan energi melalui reaksi enzim yang dihasilkan oleh mikroorganisme. Proses fermentasi dapat dikatakan sebagai proses "protein enrichment" yang berarti proses pengkayaan protein bahan dengan menggunakan mikroorganisme tertentu (Sarwono, 2001).

Sistem pencernaan kelinci merupakan sistem pencernaan yang sederhana dengan caecum dan usus yang besar. Hal ini memungkinkan kelinci dapat memanfaatkan bahanbahan hijauan, rumput dan sejenisnya. Bahan-bahan itu dicerna oleh bakteri di saluran cerna bagian bawah seperti yang terjadi pada saluran cerna . Kelinci mempunyai sifat copopraghy 
yaitu memakan feses yang sudah dikeluarkan. Feses ini berwarna hijau muda dan lembek. Hal ini terjadi karena konstruksi saluran pencernaannnya sehingga memungkinkan kelinci untuk memanfaatkan secara penuh pencernaan bakteri di saluran bagian bawah atau yaitu mengkonversi protein asal hijauan menjadi protein bakteri yang berkualitas tinggi, mensintesis vitamin B dan memecah selulose/serat menjadi energi yang berguna.

Pakan dalam bentuk pelet memiliki beberapa kelebihan yakni dapat meningkatkan selera makan/palatabilitas, pemborosan ransum akibat tumpah/terbuang dapat ditekan, dapat mengefisienkan formula ransum karena setiap butiranpelet mengandung nutrisi yang sama, ternak tidak diberi kesempatan untuk memilih-milih makanan yang disukai (Khalil,1999).

Pencernaan makanan kelinci hampir sekitar 40\%-nya dalam usus besar. Di sana terjadi pemilihan jenis makanan yang sedang dicerna, antara makanan bernutrisi dan makanan berserat. Sari makanan bernutrisi kemudian diserap oleh tubuh, sedangkan sisa makanan berserat kemudian dikeluarkan sebagai feses. Feses inilah yang kemudian dimakan kembali oleh kelinci untuk mengulang proses pencernaan yang sama, proses ini biasanya disebut dengan coprophagy.

Kelinci termasuk jenis ternak pseudo-ruminant, yaitu herbivora yang tidakdapat mencerna serat kasar dengan baik. Kelinci memfermentasi pakan di usus belakangnya. Fermentasi hanya terjadi di caecum (bagian pertama usus besar), yang kurang lebih merupakan 50\% dari seluruh kapasitas saluran pencernaannya. Sekitar umur tiga minggu kelinci mulai mencerna kembali kotoran lunaknya, langsung dari anus (proses ini disebut caecotrophy) tanpa pengunyahaan. Kotoran ini terdiri atas konsentrat bakteri yang dibungkus oleh mukus. Walaupun memiliki caecum yang besar, kelinci ternyata tidak mampu mencerna bahan-bahan organikdan serat kasar dari hijauan sebanyak yang dapat dicerna oleh ternak ruminansia murni. Daya cerna mengonsumsi hijauan daun mungkin hanya 10\% (Sarwono, 2007).

\section{BAHAN DAN METODE PENELITIAN}

\section{Lokasi dan Waktu Penelitian}

Penelitian ini dilaksanakan di Laboratorium Biologi Ternak Jl. Prof. Ahmad Sofyan No.3 Fakultas Pertanian Universitas Sumatera Utara. Penelitian ini dilaksanakan selama 10 minggu, termasuk masa adaptasi selama 2 minggu. 


\section{Bahan dan Alat}

Kelinci peranakan Rex jantan lepas sapih sebanyak 20 ekor, pelet perlakuan terdiri atas kulit daging buah kopi tanpa fermentasi, kulit daging buah kopi fermentasi, tepung jagung, bungkil kedelai, bungkil kelapa, dedak, ultra mineral, minyak makan, molases, urea,air minum, tepung daun wortel, obat-obatan dan vitamin seperti wormectin, B-complex, antibloat, rodalon sebagai desinfektan kandang. Kandungan nutrisi pada Tabel 1.

Kandang individu dengan ukuran $50 \times 50 \times 50 \mathrm{~cm}$ sebanyak 20 petak, pencetak pelet, timbangan kapasitas $10 \mathrm{~kg}$ dengan kepekaan $1 \mathrm{~g}$, tempat pakan dan tempat minum pada tiap kandang dengan total sebanyak 20 unit, mesin giling untuk membuat tepung, lampu 20 watt sebagai penerangan kandang, termometer untuk mengetahui suhu kandang, sapu lidi, sebagai alat pembersih kandang, telenan dan plastik transparan, terpal plastik sebagai alas untuk menyusun pelet, kardus sebagai tempat penyimpanan bahan untuk pelet.

Tabel 1. Komposisi dan kanddungan nutrisi ransum kelinci

\begin{tabular}{|c|c|c|c|c|c|}
\hline \multirow[t]{2}{*}{ No } & \multirow[t]{2}{*}{ Bahan Pakan } & \multicolumn{4}{|c|}{ Perlakuan } \\
\hline & & $\mathrm{P} 0$ & P1 & $\mathrm{P} 2$ & P3 \\
\hline 1 & $\begin{array}{l}\text { KDBK non } \\
\text { Fermentasi }\end{array}$ & 30 & 20 & 10 & 0 \\
\hline 2 & KDBK Fermrntasi & 0 & 10 & 20 & 30 \\
\hline 3 & Tepung Jagung & 30,00 & 30,00 & 30,00 & 30,00 \\
\hline 4 & Dedak padi & 5,00 & 5,00 & 5,00 & 5,00 \\
\hline 5 & Tepung Daun & & & & \\
\hline & Wortel & 15,00 & 15,00 & 15,00 & 15,00 \\
\hline 6 & Bungkil Kedelai & 11,00 & 11,00 & 11,00 & 11,00 \\
\hline 7 & Bungkil Kelapa & 3,60 & 3,60 & 3,60 & 3,60 \\
\hline 8 & Ultra Mineral & 0,50 & 0,50 & 0,50 & 0,50 \\
\hline 9 & Minyak Makan & 0,75 & 0,75 & 0,75 & 0,75 \\
\hline 10 & Molases & 3,00 & 3,00 & 3,00 & 3,00 \\
\hline 11 & Lysine & 0,50 & 0,50 & 0,50 & 0,50 \\
\hline 12 & Metionin & 0,50 & 0,50 & 0,50 & 0,50 \\
\hline 13 & Urea & 0,15 & 0,15 & 0,15 & 0,15 \\
\hline & Total & 100 & 100 & 100 & 100 \\
\hline & & Kandungan & trisi & & \\
\hline 1 & $\begin{array}{l}\text { Energi metabilis/EM } \\
(\mathrm{kkal} / \mathrm{mg})\end{array}$ & $2.478,82$ & $2.549,53$ & $2.620,24$ & $2.691,54$ \\
\hline 2 & Protein kasar/PK (\%) & 15,00 & 15,21 & 15,43 & 15,64 \\
\hline 3 & Serat kasar/SK (\%) & 11,94 & 11,91 & 11,87 & 11,84 \\
\hline 4 & Lemak kasar/LK (\%) & 2,55 & 2,56 & 2,56 & 2,56 \\
\hline 5 & Harga pemakaian $(\mathrm{Rp})$ & 3188,15 & 3201,55 & 3214,95 & 3228,35 \\
\hline
\end{tabular}




\section{Metode Penelitian}

\section{Rancangan Penelitian}

Metode penelitian yang digunakan adalah rancangan acak lengkap (RAL) yang terdiri dari 4 perlakuan dan 5 ulangan sehingga diperoleh 20 unit percobaan.

Adapun perlakuan yang diteliti adalah sebagai berikut:

P0 : Pelet dengan pakan basal + kulit daging buah kopi tanpa fermentasi 30\%

P1 : Pelet dengan pakan basal + kulit daging buah kopi tanpa fermentasi $20 \%$ dan kulit daging buah kopi fermentasi10\%

P2 : Pelet dengan pakan basal + kulit daging buah kopi tanpa fermentasi $10 \%$ dan kulit daging buah kopi fermentasi20\%

P3 : Pelet dengan pakan basal + kulit daging buah kopi fermentasi 30\% Model Matematik RAL adalah sebagai berikut:

$\mathbf{Y}_{\mathrm{ij}}=\mu+\sigma_{\mathrm{i}}+\varepsilon_{\mathrm{ij}}$

Keterangan :

$\mathrm{Y}_{\mathrm{ij}} \quad=$ nilai pengamatan pada perlakuan ke-i ulangan ke $\mathrm{j}$

$\mathrm{i} \quad=1,2,3,4$, (ulangan)

$\mathrm{j} \quad=1,2,3,4,5,6$ (perlakuan)

$\mu \quad=$ nilai tengah umum

$\sigma_{\mathrm{i}} \quad=$ pengaruh perlakuan ke-i

$\varepsilon_{\mathrm{ij}} \quad=$ efek galat percobaan pada perlakuan ke-i, ulangan ke-j

\section{Parameter Penelitian}

\section{Konsumsi Pakan (Bahan Kering dan Bahan Organik)}

Konsumsi bahan kering dan bahan organik diukur dengan mengalikan konsumsi ransum dengan kandungan bahan kering dan bahan organik yang diperoleh dari data analisis di laboratorium. Konsumsi bahan kering dan bahan organik dapat di rumuskan sebagai berikut:

a. Konsumsi Bahan Kering $=($ Pemberian $(\mathrm{g}) \times \% \mathrm{BK})-(\operatorname{sisa}(\mathrm{g}) \mathrm{x} \% \mathrm{BK})$

b. Konsumsi Bahan Organik $=(\mathrm{BK}$ pemberian $(\mathrm{g}) \times \mathrm{\%}$ BO $)-(\mathrm{BK}$ sisa $(\mathrm{g}) \times \mathrm{\%}$ BO $)$

\section{Kecernaan Bahan Kering (KcBK)}

Kecernaan bahan kering didapatkan dengan cara mengurangi bahan kering konsumsi dengan bahan kering feses lalu dibagi dengan bahan kering konsumsi yang kemudian dikali seratus persen. Bahan kering konsumsi didasarkan pada hasil analisis proksimat dan bahan kering feses diukur dari hasil rata-rata pengukuran bahan kering feses selama tujuh hari 
terakhir selama penelitian. Koefisien cerna bahan kering dihitung dengan menggunakan rumus:

KcBK :

(Konsumsi BK - Pengeluaran BK) $\times 100 \%$

Konsumsi BK

\section{Kecernaan Bahan Organik (KcBO)}

Kecernaan bahan organik didapatkan dengan cara mengurangi bahan organik konsumsi dengan bahan organik feses lalu bagi dengan bahan organik konsumsi yang kemudian kali seratus persen. Bahan organik konsumsi didasarkan pada hasil analisis proksimat dan bahan organik feses diukur dari hasil rata-rata pengukuran bahan organik feses selama tujuh hari terakhir selama penelitian. Koefisien cerna bahan organik dihitung dengan menggunakan rumus:

KcBO :

(Konsumsi BO - Pengeluaran BO) $\times 100 \%$

Konsumsi BO

\section{HASIL DAN PEMBAHASAN}

\section{Rekapitulasi Hasil Penelitian}

Rataan dari parameter yaitu Konsumsi bahan kering, konsumsi bahan organik, kecernaan bahan kering dan kecernaan bahan organik hasil penelitian dapat dilihat pada Tabel 2.

Tabel 2. Rekapitulasi hasil penelitian kelinci Rex jantan

\begin{tabular}{ccccc}
\hline Perlakuan & $\begin{array}{c}\text { Konsumsi } \\
\text { BK }(\mathrm{g})\end{array}$ & $\begin{array}{c}\text { Konsumsi } \\
\mathrm{BO}(\mathrm{g})\end{array}$ & $\begin{array}{c}\text { Kecernaan } \\
\text { BK }(\%)\end{array}$ & $\begin{array}{c}\text { Kecernaan } \\
\text { BO }(\%)\end{array}$ \\
\hline P0 & $81,59^{\mathrm{tn}} \pm 7,45$ & $83,54^{\mathrm{tn}} \pm 14,19$ & $59,70^{\mathrm{tn}} \pm 0,28$ & $61,28^{\mathrm{tn}} \pm 0,46$ \\
P1 & $78,86^{\mathrm{tn}} \pm 7,61$ & $83,36^{\mathrm{tn}} \pm 11,06$ & $59,75^{\mathrm{tn}} \pm 0,29$ & $61,40^{\mathrm{tn}} \pm 0,34$ \\
P2 & $82,70^{\mathrm{tn}_{ \pm}} \pm 4,90$ & $87,14^{\mathrm{tn}} \pm 10,38$ & $59,74^{\mathrm{tn}} \pm 0,19$ & $61,31^{\mathrm{tn}} \pm 0,37$ \\
P3 & $84,23^{\mathrm{tn}} \pm 3,91$ & $90,80^{\mathrm{tn}} \pm 10,80$ & $59,89^{\mathrm{tn}} \pm 0,10$ & $61,50^{\mathrm{tn}} \pm 0,29$ \\
\hline
\end{tabular}

Keterangan $\mathrm{tn}=$ tidak berbeda nyata

\section{Konsumsi Bahan Kering}

Konsumsi bahan kering dari total konsumsi ransum yang diberikan dan dihitung berdasarkan kandungan bahan keringnya. Pengambilan data konsumsi bahan kering diambil selama 7 hari terakhir dari masa penelitian pemeliharaan kelinci Rex jantan. Rataan konsumsi tertinggi yaitu pada P3 sebesar 84,23 g/ekor/hari yang diikuti berturut-turut oleh P2 sebesar 
82,70, P0 sebesar 81,59 dan rataan konsumsi terendah adalah P1 yaitu 78,86 g/ekor/hari relatif sama yang dipengaruhi oleh faktor palatabilitas ternak terhadap ransum. Hal ini sesuai dengan pernyataan Davies (1982), yang menyatakan konsumsi pakan dipengaruhi oleh palatabilitas, kuantitas, dan kualitas ransum. Selain itu, Murtidjo (1993) mengatakan bahwa konsumsi pakan dipengaruhi oleh kandungan zat-zat makanan seperti protein, karbohidrat, lemak, dan nutrisi lainnya. Hasil yang tidak berbeda ini diduga karena komposisi bahan penyusun ransum yang digunakan sama menyebabkan tingkat palabilitas dari masing-masing ransum perlakuan masih relatif sama sehingga belum mampu untuk meningkatkan daya suka ternak terhadap ransum perlakuan.

Hasil analisis ragam menunjukan hasil yang tidak berbeda nyata, hal ini menunjukan bahwa pengaruh pemberian kulit daging buah kopi fermentasi yang dicampur dengan pakan basal dalam bentuk pelet tidak berbeda nyataterhadap kulit daging buah kopi tanpa fermentasi yang dicampur dengan pakan basal dalam bentuk pelet dalam konsumsi bahan kering.

Hal ini disebabkan karena tingkat atau perbedaan konsumsi bahan kering dipengaruhi oleh kandungan nutrisi pada Tabel 1 yang terdapat diransum dan serat kasar yang terlalu tinggi sehingga daya serap kecernaan yang ada pada ternak tidak baik. Hal ini sesuai dengan pernyataan Herman (2000) yang menyatakan kelinci merupakan ternak herbivora yang bukan ruminansia, kurang mampu untuk mencerna serat kasar, tetapi dapat mencerna protein dari tanaman berserat dan memanfaatkannya dengan efektif.

Penelitian Zulharman (2010), rataan konsumsi bahan kering pelet ransum daun ubi jalar sebesar 127,41 gr/ekor/hari. Hal ini menunjukkan bahwa konsumsi bahan kering pada perlakuan kulit daging buah kopi fermentasi lebih rendah yaitu sebesar 84,23 gr/ekor/hari.

\section{Konsumsi Bahan Organik}

Konsumsi bahan organik diperoleh dengan mengalikan konsumsi ransum dengan kandungan bahan kering dan organik yang diperoleh dari data analisis di laboratorium.Pengambilan data konsumsi bahan kering diambil selama 7 hari terakhir dari masa penelitian pemeliharaan kelinci Rex jantan.

Rataan konsumsi bahan organik kelinci Rex jantan lepas sapih tertinggi adalah perlakuan P3 sebesar 90,80 g dan diikuti P2 $(87,14 \mathrm{~g})$, P0 $(83,54 \mathrm{~g})$ dan terkecil yaitu pada perlakuan P1 sebesar 83,56 g seperti halnya kecernaan bahan kering. Hal ini sesuai dengan pernyataan bahwa nilai kecernaan bahan organik berkaitan erat dengan bahan kering, sebab sebagian besar komponen dari bahan kering terdiri dari bahan organik (Tilman et al., 1998). Pendapat tersebut juga sesuai dengan pernyataan Sutardi (1990) yang menyatakan bahwa 
peningkatan kecernaan bahan organik sejalan dengan peningkatan kecernaan bahan kering sehingga faktor-faktor yang mempengaruhi tinggi rendahnya bahan kering akan mempengaruhi tinggi rendahnya bahan organik.

Hasil analisis ragam menunjukkan hasil yang tidak berbeda nyata, hal ini menunjukkan bahwa konsumsi bahan organik berbanding lurus dengan konsumsi bahan kering. Hal ini sesuai dengan pernyataan Kamal (1994), yang menyatakan bahwa konsumsi bahan kering memiliki hubungan searah dengan konsumsi bahan organik yaitu apabila konsumsi bahan kering tinggi maka dapat meningkatkan konsumsi bahan organik juga tinggi.

Penelitian Zulharman (2010), rataan konsumsi bahan organik pelet ransum daun ubi jalar sebesar 113,48 gr/ekor/hari. Hal ini menunjukkan bahwa konsumsi bahan organik pada perlakuan kulit daging buah kopi fermentasi lebih rendah yaitu sebesar 90,80 gr/ekor/hari.

\section{Kecernaan Bahan Kering (KcBK)}

Kecernaan bahan kering diperoleh dari konsumsi bahan kering dikurang pengeluaran feses dalam bentuk bahan kering dibagi dengan konsumsi bahan kering dan dikali 100\%. Pengambilan data konsumsi bahan kering diambil selama 7 hari terakhir dari masa penelitian pemeliharaan kelinci Rex jantan.

Rataan yang terbesar adalah pada perlakuan P3 (Pelet dengan pakan basal + kulit daging buah kopi fermentasi 30\%) yaitu sebesar 59,89\% dan terkecil adalah perlakuan P0 (Pelet dengan pakan basal + kulit daging buah kopi tanpa fermentasi 30\%) yaitu sebesar $59,70 \%$.

Hasil analisis ragam menunjukan bahwa pemberian kulit daging buah kopi fermentasi MOL memberikan pengaruh tidak berbeda nyataterhadap kecernaan bahan kering kelinci Rex jantan lepas sapih. Nilai kecernaan bahan kering yang diperoleh pada penelitian ini bisa dikatakan sedang karena nilainya berada diatas 50\% dan dibawah 70\%. Hal ini sesuai dengan pernyataan Harahap (2010) yang menyatakan bahwa tingkat kecernaan akan menentukan seberapa besar gizi yang terkandung dalam bahan pakan secara potensial dapat dimanfaatkan untuk produksi ternak. Kecernaan nutrisi tinggi bila nilainya $70 \%$ dan rendah bila nilainya lebih kecil dari 50\%.

Penelitian Zulharman (2010), rataan kecernaan bahan kering pelet ransum daun ubi jalar sebesar 70,46 \%. Hal ini menunjukkan bahwa kecernaan bahan kering pada perlakuan kulit daging buah kopi fermentasi lebih rendah yaitu sebesar 59,89\%. 


\section{Kecernaan Bahan Organik (KcBO)}

Kecernaan bahan organik didapatkan dengan cara mengurangi bahan organik konsumsi dengan bahan organik feses lalu bagi dengan bahan organik konsumsi yang kemudian kali seratus persen.Pengambilan data konsumsi bahan kering diambil selama 7 hari terakhir dari masa penelitian pemeliharaan kelinci Rex jantan.

Rataan yang terbesar adalah pada perlakuan P3 (Pelet dengan pakan basal + kulit daging buah kopi fermentasi 30\%) yaitu sebesar 61,50\% diikutin dengan $\quad$ P1 $(61,40)$, P2 $(61,31)$ dan terkecil adalah perlakuan P0 (Pelet dengan pakan basal + kulit daging buah kopi tanpa fermentasi 30\%) yaitu sebesar 61,28\%,. Rataan kecernaan bahan organic dan kecernaan bahan kering cenderung berbanding lurus atau sejalan. Hal ini sesuai dengan pernyataan Tillman et al. , (1991) yang menyatakan bahwa sebagian besar bahan organik merupakan komponen bahan kering.

Hasil analisis ragam menunjukan hasil yang tidak berbeda nyata terhadap kecernaan bahan organik. Hal ini menunjukan bahwa pemberian kulit daging buah kopi fermentasi MOL yang dicampur dengan pakan basal dalam bentuk pelet tidak berpengaruh nyata terhadap kecernaan bahan organik, dikarenakan kandungan zat anti nutrisi dari kulit daging buah kopi yang tinggi seperti serat kasar, lignin, dan tiobromin, hal ini sesuai dengan pernyataan Wong et al., (1987) yang menyatakan kulit buah kopi tidak dapat diberikan pada ternak monogastrik karena kandungan lignin yang cukup tinggi yaitu mencapai 38,70\% serta adanya theobromin dan terdapat anti nutrisi tanin yang menjadi pembatas penggunaan kulit buah kopi ini. Tetapi cenderung kearah yang lebih baik karena nilai kecernaan yang diperoleh diatas nilai $50 \%$ karena di dalam MOL tersebut terdapat bakteri lactobacillus yang baik terhadap kecernaan kelinci. Hal ini sesuai dengan pernyataan Buckle (1987) yang menyatakan bahwa Lactobacillus sp menghasilkan asam laktat yang dapat menguraikan bahan organik dengan cepat.

Penelitian Zulharman (2010), kecernaan bahan organik pelet ransum daun ubi jalar sebesar 71,91\%. Hal ini menunjukkan bahwa kecernaan bahan organik pada perlakuan kulit daging buah kopi fermentasi lebih rendah yaitu sebesar $61,50 \%$.

\section{KESIMPULAN}

Fermentasi MOL (mikro organism lokal) pada daging kulit buah kopi tidak signifikan (tidak mempengaruhi) terhadap daya cerna pada kelinc rex. Disarankan tidak melakukan fermentasi terhadap daging kulit buah kopi sebagai pakan kelinci rex. 


\section{DAFTAR PUSTAKA}

Buckle, K.A. Edwar, R.A. Fleet, G.H. Woodon, M.M. 1987. IlmuPangan. Jakarta: UI-Press.

Davies, H.L. 1982. Nutrition and Growth. Hedges and belly Pty. Ltd. Melbaurne.

Harahap, N., 2010. Uji Kecernaan Bahan Kering, Bahan Organik, KadarNH3 dan VFA pada Jerami Jagung, Pelepah Daun Sawit Terolah pada Kelinci. Bioindustri Penerapan Teknologi Fermentasi. Mediyatama Sarana. Perkasa, Jakarta.

Herman, R. 2000. Produksi Kelinci dan Marnot. Anatomi dan Fisiologi alat Pencernaan serta Kebutuhan Pakan. Edisi ke-3. Fakultas Peternakan. Institut Pertanian Bogor. Bogor.

Kamal, M., 1994. Nutrisi Ternak 1. Fakultas Peternakan Universitas Gadjah Mada. Yogyakarta. Hal. 141.

Khalil., 1999. Khalil Kandungan Air dan Ukuran Partikel Terhadap Sifat Fisik Pakan: Kerapatan Tumpukan, Kerapatan Pemadatan Tumpukan dan Berat Jenis. Media Peternakan 22 (1) : 1-11.

Murtidjo, B.A., 1993. Memelihara Kambing Sebagai Ternak Potong dan Perah. Penerbit Kanisius. Yogyakarta.

Sarwono, B., 2001. Kelinci Potong dan Hias. Agromedia Pustaka, Jakarta.

., 2002. Kiat Mengatasi Permasalahan Praktis Kelinci Potong dan Hias. Agromedia Pustaka. Jakarta.

2003. Kelinci Potong dan Hias. Agro Media Pustaka. Jakarta.

Sutardi, T. 1979. "Ketahanan Protein Bahan Makanan Terhadap Degradasi oleh Mikroba dan Manfaatnya bagi Peningkatan Produktivitas Ternak. Prosiding Seminar Penelitian dan Pengembangan Peternakan. Lembaga Penelitian dan Pengembangan.

Tillman, A. D., H. Hartadi., S. Reksohadiprodjo., S. Prawitokusumo., S. Lebdosoekojo., 1991. Ilmu Makanan Ternak

Tillman, A.D., H. Hartadi, S. Reksohadiprojo, S. Prawirokusumo. dan S. Lebdosoekojo. 1998. Ilmu Makanan Ternak Dasar. Edisi Keenam. Gadjah Mada University Press. Yogyakarta.

Wong, H. K., A. H. Osman and M. S. Idris. 1987. Utilization of cocoa by-product as ruminant feed. In: Dixon, R.M (Ed). Ruminant Feeding System Utilizing Fibrous Agricultural Residues. 1986. School of Agriculture and Forestry. University of Melbourne.Parkville. Victoria.

Zulharman, Dicky. 2010. Kecernaan Bahan Organik dan Protein Kasar Pelet dan Silase Ransum Komplit pada kelinci Jantan Lokal. IPB Press. Bogor.. 
Jurnal Peternakan Integratif Vol. 3 No.3 :319-328 